\title{
Drought in Polish Forests in 2015
}

\author{
Andrzej Boczoń*, Anna Kowalska, Małgorzata Dudzińska, Michał Wróbel
}

Forest Research Institute, Braci Leśnej 3, 05090 Sękocin Stary, Poland

Received: 15 February 2016

Accepted: 22 April 2016

\begin{abstract}
One effect of global warming is the increasing risk of drought. The shortage of water in the soil has a direct impact on crop plants. It can therefore be expected that drought stress will negatively affect forests. The aim of this study was to determine the length of the drought in the forests of Poland in 2015. Calculations were carried out using data from 21 meteorological stations for the conditions prevailing in the reference stand, which was determined to be a middle-aged pine stand growing on poor sandy soils classified as Dystric Arenosol. Drought was treated as the state when the soil water available to plants is depleted up to a depth of one meter. Daily changes in soil water storage were measured on the basis of the balance of water inflow-outflow. Climatic water balance was also determined. The calculations of the soil water storage deficit for the conditions of the reference forest ecosystem showed that in 2015 drought soil occurred in almost all of the forests of Poland. Wielkopolska was affected by the earliest-starting and longest-lasting drought. To a lesser extent, however, it extended throughout all of central Poland, from the west to the eastern border of the country. This is where one could expect to see the negative effects of the lack of water available to trees, which can be manifested as a smaller increase in growth, a decrease in health status, and - in particularly unfavorable conditions - dying trees. The climatic water balance showed that the annual water deficit in Wielkopolska exceeded $100 \mathrm{~mm}$.
\end{abstract}

Keywords: drought, soil water storage, forest, water balance

\section{Introduction}

One of the effects of global warming is the increasing risk of the occurrence of droughts. On a global scale, there has been an increase in the percentage of area annually affected by droughts from 1902 to 2008 [1]. And since 1970 , increases in the intensity and duration of droughts as well as growth in areas affected by droughts have been observed [2-3]. Climate models predict a future reduction of the average annual precipitation in large areas of the northern hemisphere, with a simultaneous increase in air temperature [4]. As a result, evaporation will increase

*e-mail: a.boczon@ibles.waw.pl and droughts will become an increasingly common phenomenon, growing in intensity and duration [5]. The statistically significant increase in reference evapotranspiration occurred in Poland in 1971-2010 as a result of the increasing trends of both air temperature (mean increase in the growing season by $0.5^{\circ} \mathrm{C}$ per 10 years) and the hours of sunshine [6]. Crop plants are directly impacted by a shortage of soil water. Consequently, the threat of droughts will primarily affect agriculture [7-8] as well as forestry.

Drought stress is regarded as an important threat to the vitality and growth of trees, and could eventually lead to their death [9]. For northwestern Europe, climate models predict higher average annual temperatures and changes in precipitation patterns, causing wetter winters but hotter 
and drier summers [10]. Forecasts suggest that the forests of northern Europe will receive an increased supply of water in spring, but will be subject to more frequent and intense droughts in summer [11]. In Poland after 1950, the droughts in 1951, 1969, 1982, 1992, 1994, 2006, and 2011 had the most negative effects on agriculture [12].

Currently, the need has been identified to determine the occurrence of droughts, the areas affected, and their frequency and severity on a global scale, but also at the national level, as this could provide the basis for developing strategies to mitigate its effects [1]. In Poland, the occurrence of droughts in forests and its impact on them has been studied mainly on a local scale, e.g., in Białowieża Primeval Forest [13], Niepołomice Forest [14], and Silesian Beskid [15]. Large-scale studies of the impact of droughts on forests in the whole country are particularly lacking.

The aim of this study was to determine the forest areas of Poland that were affected by soil drought in 2015, as well as to determine the duration of the drought and the dates when the soil water deficits began and ended.

\section{Material and Methods}

Defining drought conditions was based on determining the availability of soil water for plants in the reference forest ecosystem, designated as the most strongly representative of Polish forests - a middle-aged pine forest growing on poor, sandy soils classified as Dystric Arenosol [16]. The characteristics impacting the water cycle in the reference forest ecosystem were defined in forest areas that are intensely monitored as part of the ICPForests Program [17].

The forest ecosystem strongly influences the water cycle in the environment. One of the most important properties of the forest is its ability to retain part of the

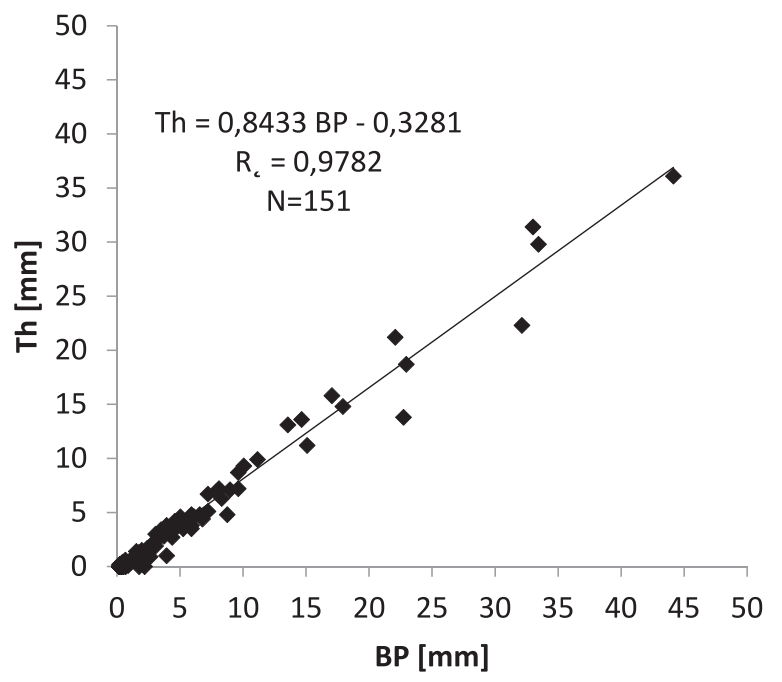

Fig 1. The relationship between bulk precipitation (BP) and throughfall (Th) in the reference tree stand (based on our own studies).
Table 1. Soil moisture $\left[\mathrm{cm}^{3} \mathrm{~cm}^{-3}\right]$ at points of the $\mathrm{pF}$-curve at four levels of Dystric Arenosol.

\begin{tabular}{|c|c|c|c|c|c|c|}
\hline \multirow{2}{*}{ depth } & \multicolumn{6}{|c|}{$\mathrm{pF}$-curve point } \\
\cline { 2 - 7 } & 0.001 & 1.0 & 2.0 & 3.0 & 3.7 & 4.2 \\
\hline $10 \mathrm{~cm}$ & 0.457 & 0.418 & 0.225 & 0.071 & 0.054 & 0.045 \\
\hline $25 \mathrm{~cm}$ & 0.450 & 0.428 & 0.232 & 0.055 & 0.042 & 0.034 \\
\hline $50 \mathrm{~cm}$ & 0.470 & 0.424 & 0.210 & 0.044 & 0.037 & 0.028 \\
\hline $85 \mathrm{~cm}$ & 0.356 & 0.324 & 0.190 & 0.035 & 0.032 & 0.028 \\
\hline
\end{tabular}

precipitation through the process of interception. In order to determine the actual precipitation reaching the soil in the reference forest ecosystem, the relationship was determined between bulk precipitation (BP) and throughfall (Th) (Fig. 1).

The curve of the water retention of Dystric Arenosol soil ( $\mathrm{pF}$ curve) to a depth of $100 \mathrm{~cm}$ (Table 1) was determined in the laboratory. Based on this, we calculated the limit values of soil water storage (SWS) to a depth of $100 \mathrm{~cm}$, where: $\mathrm{pF}=2.0$ - field capacity $(\mathrm{FC})$; $\mathrm{pF}=3.7$ - early wilting point (EWP), value close to referred to as initial wilting point by Imanishi et al. [18]); $\mathrm{pF}=4.2$ - permanent wilting point (PWP) and determined readily available water (RAW), which is equal to the maximum SWS.

The moment of soil drought was determined as the total depletion of RAW $(2.0<\mathrm{pF}<3.7)$, which was $170.9 \mathrm{~mm}$, equivalent to a decrease in the amount of water below $\mathrm{pF}=3.7(38.9 \mathrm{~mm})$.

$$
S W S_{i}<S W S_{p F=3.7}
$$

Actual soil water storage (SWS) was calculated for each day, based on the balance of water outflow due to the process of evapotranspiration and water inflow from precipitation, according to the formula:

$$
S W S_{(i+1)}=S W S_{i}+T h_{i}-E V T_{i}
$$

...where:

SWS - soil water storage [mm]

$i$ - number of the day

$E V T$ - daily evapotranspiration [mm]

Th - daily throughfall $[\mathrm{mm}]$

$$
T h=0,8433 \cdot B P-0,3281
$$

...where:

$B P$ - bulk precipitation [mm]

Evapotranspiration of the ecosystem was calculated using Makkink's equation according to DVWK [19]:

$$
E V T=\frac{\Delta}{\Delta+\gamma}\left(0,61 \frac{R_{n}}{\lambda}-0,12\right)
$$


... where $R_{n}$ is solar radiation [MJ m${ }^{-2}$ day $\left.^{-1}\right], \Delta$ is the slope of saturation vapour pressure curve $\left[\mathrm{kPa}^{\circ} \mathrm{C}^{-1}\right], \lambda$ is latent heat of vaporization $\left[\mathrm{MJ} \mathrm{m}^{-2} \mathrm{~mm}^{-1}\right.$, and $\gamma$ is psychrometric constant $\left[\mathrm{kPa}^{\circ} \mathrm{C}^{-1}\right]$. This method provides good results in calculating the reference evapotranspiration of a ca. 70-year-old pine ecosystem [20].

According to the principles of soil water retention, calculations were performed with the following boundary conditions:

1. SWS at $\mathrm{pF}=2.0(209.8 \mathrm{~mm})$ : the upper limit of the amount of water that can be retained in the soil to a depth of $100 \mathrm{~cm}$; above this value, water flows out of the profile.

2. SWS at $\mathrm{pF}=4.2(31.8 \mathrm{~mm})$ : the lowest limit of the amount of water that can be found under natural conditions in the soil to a depth of $100 \mathrm{~cm}$.

Calculations were performed for all of the days of 2015 assuming that on January 1 the soil is fully saturated with water, i.e., the soil water content is equal to $\mathrm{FC}$ with a value of $209.8 \mathrm{~mm}$. This assumption is justified because soil water is replenished in winter under Poland's climatic conditions.

On the basis of evapotranspiration calculations using Makkink's method, we also calculated the climatic water balance BP-EVT.

The calculations were made on the basis of measurements at meteorological stations of the Forest Research Institute located in the forest districts of Bircza, Hajnówka, Suwałki, Jakuszyce, Szklarska and the state forests national forest holding districts of Bydgoszcz, Cewice, Cybinka, Dobieszyn, Gościno, Krotoszyn, Kup, Łagów, Niepołomice, Parciaki, Płońsk, Poddębice, Rudy, Spychowo, Susz, Włodawa, and Wronki (Fig. 2).

In the case of the stations in Hajnówka and Suwałki, we used the direct measurements of throughfall in the tree stands of the ICP-Forests area for the calculation due to a

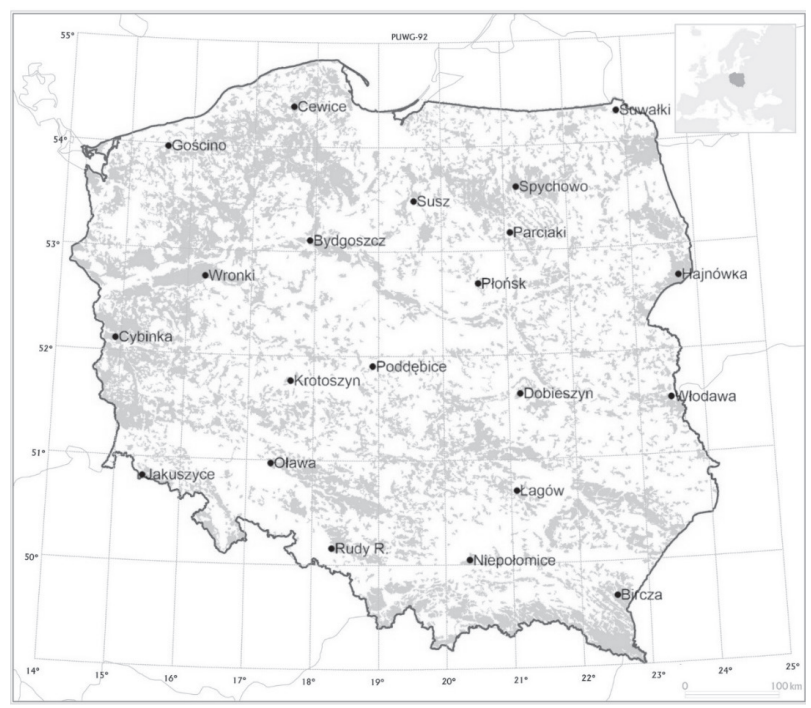

Fig. 2. Spatial distribution of forests in Poland (map provided by Bureau for Forest Management and Geodesy Regional Office in Białystok for [21]) and location of meteorological stations. temporary malfunction of the precipitation sensor at the meteorological stations. Calculations for Włodawa were based on precipitation measurements from the Chełm station for similar reasons.

Determining the contour lines for the range of the drought was done with the SURFER 13 program, using the boundaries provided by Poland's Central Geodetic and Cartographic Documentation Centre (www.codgik.gov.pl/ index.php/darmowe-dane).

\section{Results and Discussion}

Forests in Poland cover 9.2 million hectares (spatial distribution presented in Fig. 2). Poland's forests are mainly pine stands or dominated by pine growing on poor sandy soils, thus the water conditions prevailing in the soil of such ecosystems can be considered to be predisposed to drought. However, droughts will impact all habitats, including wetlands and marshes. In wet and marshy areas, drought leads to a decrease in the level of groundwater. As a result, water resources become unavailable to vegetation.

Actual SWS are highly variable in the data from specific meteorological stations (Fig. 3). Results for several

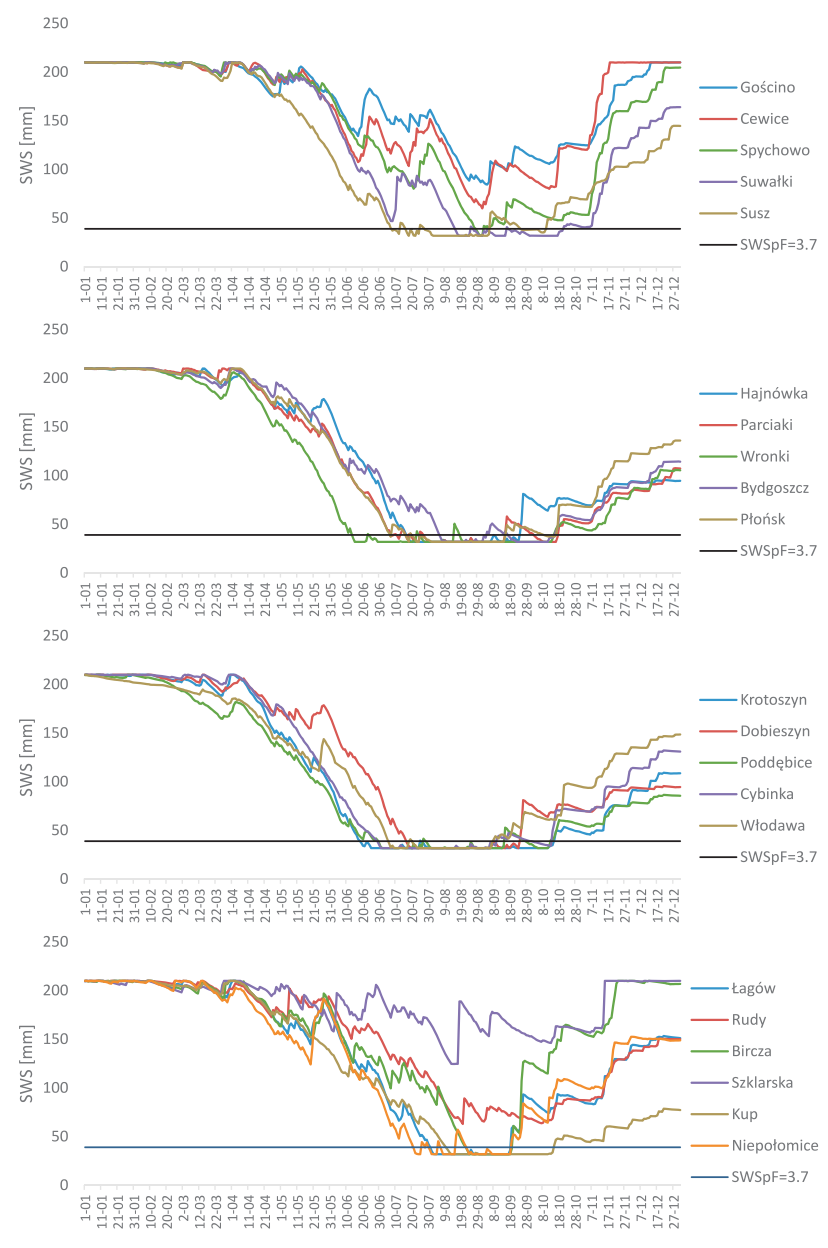

Fig. 3. Estimation of actual soil water storage for the reference forest ecosystem. 
locations did not show a SWS deficit in 2015, including Cewice, Gościno, Rudy, and Szklarska. Soil drought was noted at other measurement sites, but they varied in terms of start date, end date, and duration of SWS deficit. Wronki (14 June) and Krotoszyn (19 June) experienced the earliest dates on which water became unavailable to plants. In late June, drought began in Poddębice and Cybinka; in July in Włodawa, Plonsk, Parciaki, Susz, Dobieszyn, and Niepołomice; and in August in all other locations. The latest start date was in Spychowo on August 28. The early onset of drought in Krotoszyn and Wronki meant that the duration of the SWS deficit was the longest there at 117 days in both cases. At the other measurement sites, the number of days of soil water deficit did not exceed 100, and it was 90 in Poddębice, 87 in Cybina, 74 in Parciaki, 70 in Susz and Płońsk, 67 in Dobieszyn, 66 in Kup, 65 in Hajnówka, 63 in Włodawa and Suwałki, 58 in Bydgoszcz, 49 in Łagów, 47 in Niepołomice, 29 in Bircza, and five in Spychowo.

The spatial distribution of the drought (Fig. 4) indicates that it lasted the longest in Wielkopolska. It largely affected the whole central part of the country and the northeastern borderlands. The duration of the drought exceeded 60 days in these areas. One can assume that the drought did not affect only Poland, but also included large areas of Belarus and Germany. Eastern Germany is considered an area highly threatened by the occurrence of droughts [22]. The duration of drought is an important parameter, since trees react primarily to the length of the drought and not to its intensity [23].

A drought that lasted for more than 100 days affected the forest area of ca. 350,000 ha, including Wielkopolski National Park and 21 forest districts. Tree stands consisting mainly of Scots pine (e.g., Notecka Forests), but also oak stands (e.g., the Krotoszyn Forest District) experienced the longest drought in 2015. Specific tree species have varying degrees of susceptibility to the adverse effects of drought stress, which causes malfunctions in the conduction of water through the wood. It is generally accepted that

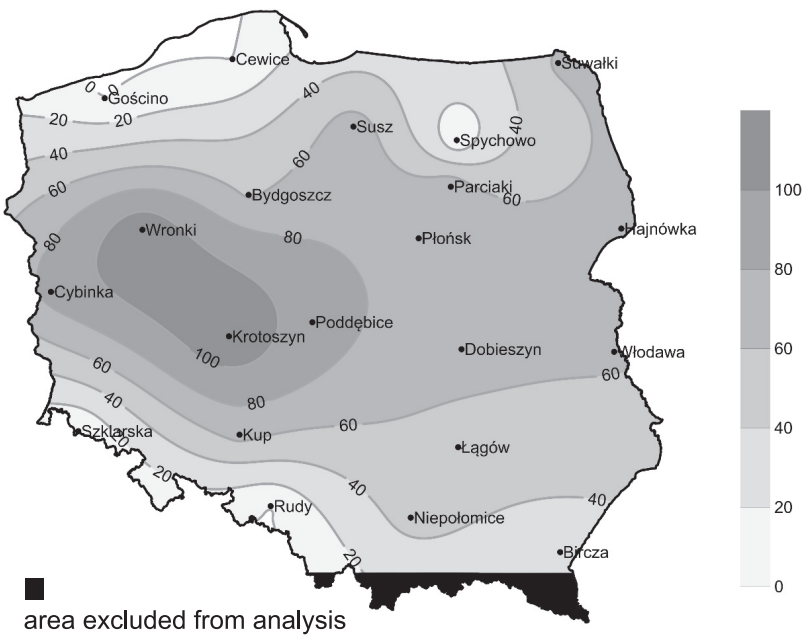

Fig. 4. Number of days of drought in the forests of Poland in 2015 . gymnosperms have a greater hydraulic safety margin than angiosperms in response to drought [24]. Among the more sensitive species growing in Poland is pedunculate oak Quercus robur L., which easily experiences problems in conducting water through the wood due to embolism. Studies found that summer droughts inhibit the growth of oaks, and the recurring droughts in the coming years will lead to their gradual weakening and dying [25]. It has been pointed out that the increased frequency of droughts caused by global warming will increase the mortality of pedunculate oaks [26]. Therefore, in the next few years we should expect oaks in the areas with the longest duration of water deficit in 2015 to exhibit the negative effects of drought stress. Drought stress does not necessarily lead to the death of trees, but it strongly affects their growth. Summer drought, mainly due to low rainfall and high evaporation, reduces the growth of various species of deciduous trees (Fagus sylvatica, Tilia cordata, Acer pseudoplatanus, Prunus avium, Alnus glutinosa, Fraxinus excelsior, Quercus robur, Betula pendula, Salix alba), even those growing on fertile soils with favorable water conditions and nutrients [27].

Forests in Poland are mainly comprised of Scots pine. Although it is recognized as a hardy species, this does not exclude the possibility of its dying as a result of drought stress [28]. It has been shown that an increase in the radial growth of pine is relatively strongly correlated with climate parameters related to the availability of water in summer [29]. It is believed, however, that due to the small number of species making up the forests of central Europe, Scots pine may be the main species enabling us to adapt forests to climate warming [22]. In areas where climate change will cause more droughts in the future, the composition of forests should be gradually changed to species with greater tolerance to drought stress [23].

From the point of view of the development and growth of trees, the timing of a drought is important. Physiologically active wood is created early in the first phase of growth during the growing season. Therefore,

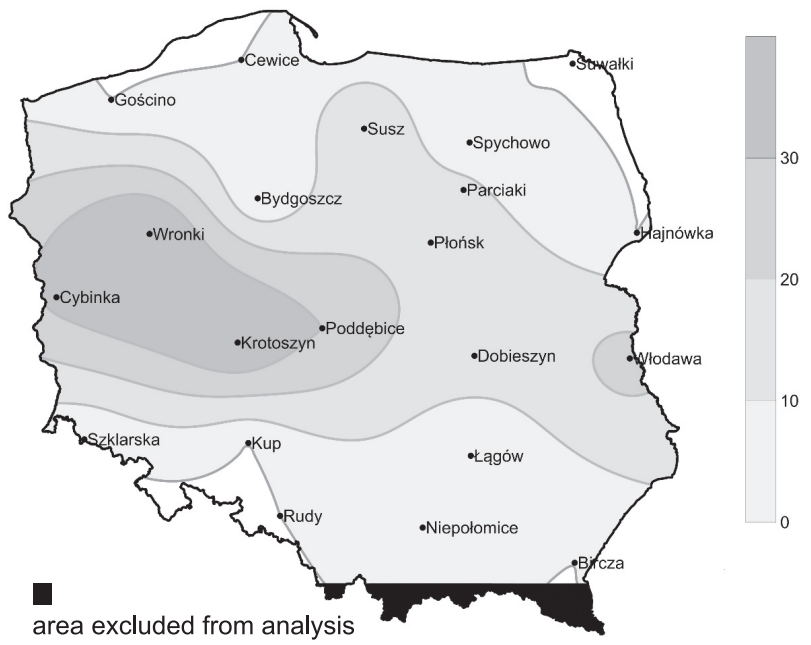

Fig. 5. The number of days of soil water deficit to the end of July 2015 . 


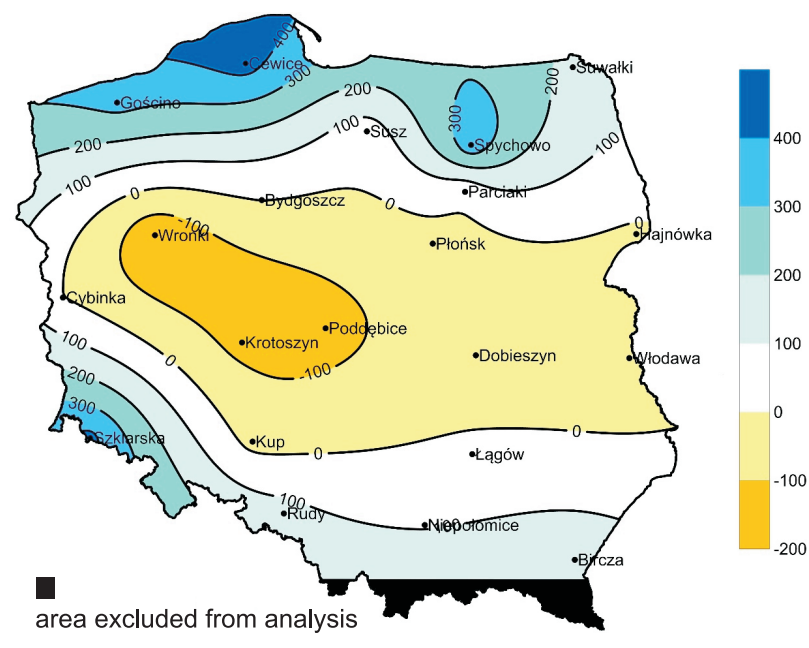

Fig. 6. Climatic water balance (BP-EVT) in Poland in 2015.

the most negative effects are caused by droughts occurring in the first months of the growing season. Fig. 5 shows the number of days of soil water deficit occurring by the end of July 2015 in Polish regions. The analysis shows that the worst conditions in the first phase of growth were in the Wielkopolska region and in the area of Włodawa. However, drought did not occur during this period in northeastern Poland.

Water shortages have been occurring in the Wielkopolska region for many years. The projected precipitation deficit in 2015 was expected to be over 200 $\mathrm{mm}$ in the region and extend to the entire country [30]. BP-EVT calculations show a distribution of the deficit consistent with the forecast. However, its range is limited to central Poland, where it maximally exceeded $100 \mathrm{~mm}$ (Fig. 6), whereas no deficit was recorded in the northern and southern parts of Poland. The differences obtained in the results compared to the forecast probably result from differences in the methodology for calculating surface evaporation, because the forecast method used Thornthwaite's method for determining potential evapotranspiration and we used Makkink's method, which is closer for reference evapotranspiration.

One of the threats caused by the increased incidence of drought is reduced forest biodiversity. In multiple-species tree stands, there is a greater reduction of soil water availability during dry growing seasons than in singlespecies stands [5]. This will lead to the formation of singlespecies tree stands, as indicated by research on changes in the pine-oak forests of the Mediterranean region [31].

The appearance of forests in the future will be determined by droughts, which change the structure and composition of tree stands. Understanding the spatial and temporal distribution of droughts and their relationship with the tree species growing in these areas, as well as taking into account the vulnerability of individual species to drought stress, are important for the development and implementation of forest management practices [32].

\section{Conclusion}

The calculations of deficits in soil water storage for the reference forest ecosystem show that in 2015, soil drought occurred in the forests in almost all of Poland. The drought of the longest duration, with the earliest start date encompassing the growth period, mainly affected the Wielkopolska region. This drought also affected all of central Poland, from the western to the eastern border of the country (however, to a lesser degree). The negative effects of the lack of water available to trees are expected in this area, which can be manifested as smaller increases in growth, decreased health status, and - in particularly unfavorable habitat conditions - dying trees. The experiences of other researchers show that over the years, repeated droughts in the same area can cause changes in the species composition of forests in the direction of reduced diversity and the emergence of single-species tree stands [5, 31-32].

The approach presented above can provide a basis for establishing a system of drought monitoring in Polish forests. The system can be a valuable tool in the decisionmaking process for protecting tree stands.

\section{Acknowledgements}

This work was financially supported by The Polish State Forests National Forest Holding [grant Nos. 500404 and BLP385].

\section{References}

1. WANG Q., WU J., LEI T., HE B., WU Z, LIU M, MO X., GENG G., LI X., ZHOU H., LIU D. Temporal-spatial characteristics of severe drought events and their impact on agriculture on a global scale. Quaternary International, 349, 10, 2014.

2. BLUNDEN J., ARNDT D., BARINGER M. State of the Climate in 2010. Bulletin of the American Meteorological Society 92 (6), 2011.

3. BURKE E.J., BROWN S.J., CHRISTIDIS N. Modeling the recent evolution of global drought and projections for the twenty-first century with the Hadley Centre climate model. Journal of Hydrometeorology 7 (5), 1113, 2006.

4. IPCC, Climate change 2013: the physical science basis. IPCC, Cambridge, 2013.

5. GROSSIORD CH., GRANIER A., GESSLER A., JUCKER T., BONAL D. Does Drought Influence the Relationship Between Biodiversity and Ecosystem Functioning in Boreal Forests? Ecosystems, 17, 394, 2014. DOI: 10.1007/s10021013-9729-1

6. ŁABĘDZKI L., BĄK B., SMARZYŃSKA K. SpatioTemporal Variability and Trends of Penman-Monteith Reference Evapotranspiration (FAO-56) in 1971-2010 under Climatic Conditions of Poland, Polish Journal of Environmental Studies 23, 2083, 2014. DOI: 10.15244/pjoes/27816

7. WALCZAK F., TRATWAL A., BOCIANOWSKI J. Effects of Changes in Precipitation and Temperature on Select Agrophage Risk in Poland, 1965-2009. Polish Journal of 
Environmental Studies, 24 (1), 325, 2015. DOI: 10.15244/ pjoes $/ 27820$

8. ŁABĘDZKI L., Estimation of local drought frequency in central Poland using the standardized precipitation index SPI. Irrigation and Drainage 56, 67, 2007. DOI: 10.1002/ ird. 285

9. ALLEN C.D., MACALADY A.K., CHENCHOUNI H., BACHELET D., MCDOWELL N., VENNETIER M., KITZBERGER T., RIGLING A., BRESHEARS D.D., HOGG E.H., GONZALEZ P., FENSHAM R., ZHANG Z., CASTRO J., DEMIDOVA N., LIM J.-H., ALLARD G., RUNNING S.W., SEMERCI A., COBB N. A global overview of drought and heat-induced tree mortality reveals emerging climate change risks for forests. Forest Ecology and Management 259, 660, 2010. DOI:10.1016/j.foreco.2009.09.001.

10. LINDNER M., MAROSCHEK M., NETHERER S., KREMER A., BARBATI A., GARCIA-GONZALO J., SEIDL R., DELZON S., CORONA P., KOLSTRÖM M., LEXER M.J., MARCHETTI M. Climate change impacts, adaptive capacity and vulnerability of European forest ecosystems. Forest Ecology and Management, 259, 698, 2010.

11. SCHARNWEBER T., MANTHEY M., CRIEGEE C., BAUWE A., SCHRÖDER C., WILMKING M. Drought matters declining precipitation influences growth of Fagus sylvatica L. and Quercus robur L. in north-eastern Germany. Forest Ecology and Management 262, 947, 2011.

12. LORENZ H. Drought and maximum precipitation in Poland. Seminarium PK GWP, 16.12.2011 (http://gwppl.org/ data/uploads/prezentacje/Susze\%20i\%20opady\%20maksymalne $\% 20 w \% 20$ Polsce.pdf) [In Polish].

13. MICHALSKI J., STARZYK J. R., KOLK A., GRODZKI W. Threat of Norway spruce caused by the bark beetle Ips typographus (L.) in the stands of the Forest Promotion Complex «Białowieża Primeval Forest» in 2000-2002. Leśne Prace Badawcze, 3, 5, 2004 [In Polish].

14. BEDNARZ Z. Niedobory wody przyczyną depresji przyrostowych u dębu (Quercus robur L.) w Puszczy Niepołomickiej, Sylwan nr 10, 29, 1994. Water deficyt causes a reduction in growth in oak in the Niepołomice Forest [In Polish].

15. DURŁO G.D., MAŁEK S., SOCHA J. Extreme precipitation events in the Forest Promotion Complex of Silesian Beskid. Folia Forestalia Polonica, series A, 57 (1), 18, 2015. DOI: 10.1515/ffp-2015-0003

16. IUSS WORKING GROUP WRB. World reference base for soil resources 2006. $2^{\text {nd }}$ edition. World Soil Resources Reports 103, 2006.

17. VAN DOBBEN H, DE VRIES W. Relation between forest vegetation, atmospheric deposition and site conditions at regional and European scales. Environmental Pollution, 158, 3, 921, 2010, DOI:10.1016/j.envpol.2009.09.015.

18. IMANISHI J., MORIMOTO Y. IMANISHI Y., SUGIMOTO K., ISODA K. The independent detection of drought stress and leaf density using hyperspectral resolution data. Landscape and Ecological Engineering, 3, 55, 2007, DOI 10.1007/s11355-007-0019-y.

19. DVWK, ERMITTLUNG DER VERDUNSTUNG VON LAND- UND WASSERFLÄCHEN. (HRSG.) Deutscher Verband für Wasserwirtschaft und Kulturbau e.V. DVWKMerkblätter zur Wasserwirtschaft, Bonn, 238. 1996.

20. BOCZOŃ A., BRANDYK A., WRÓBEL M., KOWALSKA A. Transpiration of a stand and evapotranspiration of Scots pine ecosystem in relation to the potential evapotranspiration estimated with different methods Sylwan 159 (8) 666, 2015. [In Polish].
21. CZEREPKO J. [ED],, BOCZOŃ A., CIEŚLA A., FORYCKA A., KSEPKO M., OBIDZIŃSKI A., PALUCH R., RODZIEWICZ A., RÓŻAŃSKI W., SOKOŁOWSKI K., SZWED W., WRÓBEL M. The state of forest biological diversity in Poland on the basis of forest monitoring plots. Forest Research Institute, Sękocin Stary, 138, 2008 [In Polish].

22. ALBERT M., HANSEN J., NAGEL J., SCHMIDT M., SPELLMANN H. Assessing risks and uncertainties in forest dynamics under different management scenarios and climate change. Forest Ecosystems 2, 14, 2015. DOI 10.1186/ s40663-015-0036-5

23. GUSTAFSON E.J., STURTEVANT B.R. Modeling Forest Mortality Caused by Drought Stress: Implications for Climate Change Ecosystems, 16, 60, 2013. DOI: 10.1007/ s10021-012-9596-1

24. CHOAT B., JANSEN S., BRODRIBB T.J., COCHARD H., DELZON S., BHASKAR R., BUCCI S.J., FEILD T.S., GLEASON S.M., HACKE U.G., JACOBSEN A.L., LENS F., MAHERALI H., MARTÍNEZ-VILALTA J., MAYR S., MENCUCCINI M., MITCHELL P.J., NARDINI A., PITTERMANN J., PRATT R.B., SPERRY J.S., WESTOBY M., WRIGHT I.J., ZANNE A.E. Global convergence in the vulnerability of forests to drought. Nature 491 (7426), 752 2012.

25. SOHAR K., HELAMA S., LÄÄNELAID A., RAISIO J., TUOMENVIRTA H. Oak decline in a southern Finnish forest as affected by a drought sequence. Geochronometria 41 (1), 92, 2013. DOI 10.2478/S13386-013-0137-2

26. URLI M., LAMY J.-B., SIN F., BURLETT R., DELZON S., PORTE A.J. The high vulnerability of Quercus robur to drought at its southern margin paves the way for Quercus ilex. Plant Ecology, 216, 177, 2015. DOI 10.1007/s11258014-0426-8

27. WEEMSTRA M., EILMANN B., SASS-KLAASSEN U.G.W., STERCK F.J. Summer droughts limit tree growth across 10 temperate species on a productive forest site. Forest Ecology and Management, 306, 142, 2013.

28. DOBBERTIN M., WERMELINGER B., BIGLER C., BÜRGI M., CARRON M., FORSTER B., GIMMI U., RIGLING A. Linking increased drought stress to Scots pine mortality and bark beetle infestations. Scientific World Journal 7 (S1), 231, 2007. DOI:10.1100/tsw.2007.58.

29. EILMANN B., ZWEIFEL R., BUCHMANN N., PANNATIER E.G., RIGLING A. Drought alters timing quantity and quality of wood formation in Scots pine. Journal of Experimental Botany 62, 2763, 2011.

30. ZIERNICKA-WOJTASZEK A., ZAWORA T. Pluviothermal Conditions in Poland in Light of Contemporary Climate Change and Their Consequences for Agriculture and Water Management. Polish Journal of Environmental Studies, 24 (1), 419, 2015.

31. GROSSIORD Ch., FORNER A., GESSLER A., GRANIER A., POLLASTRINI M., VALLADARES F., BONAL D. Influence of species interactions on transpiration of Mediterranean tree species during a summer drought. European Journal of Forest Research, 134, 365, 2015. DOI 10.1007/s10342-014-0857-8

32. PETERS M.P., IVERSON L.R., MATTHEWS S.N. Longterm droughtiness and drought tolerance of eastern US forests over five decades. Forest Ecology and Management, 345, 56, 2015. 